\title{
Biological Behavior and Partial Molecular Characterization of Six Chilean Isolates of Plum pox virus
}

\author{
F. Reyes, Biotechnology Laboratory, Instituto de Investigaciones Agropecuarias (INIA) - Centro Regional de Inves- \\ tigación La Platina, Santiago, Chile; N. Fiore, Facultad de Ciencias Agronómicas, Universidad de Chile, Santiago, \\ Chile; and M. A. Reyes, P. Sepúlveda, V. Paredes, and H. Prieto, Biotechnology Laboratory, Instituto de Investi- \\ gaciones Agropecuarias (INIA) - Centro Regional de Investigación La Platina, Santiago, Chile
}

\begin{abstract}
Reyes, F., Fiore, N., Reyes, M. A., Sepúlveda, P., Paredes, V., and Prieto, H. 2003. Biological behavior and partial molecular characterization of six Chilean isolates of Plum pox virus. Plant Dis. $87: 15-20$.

Plum pox virus (PPV) strain D was first detected in Chile in 1992 infecting Prunus trees including peaches, nectarines, apricots, and plums. Since then, quarantine efforts have included periodic surveys in the central zone of the country, the main region for stone fruit production. This work describes the characterization of six PPV isolates from this area of Chile, using biological and molecular approaches. PPV isolates were introduced into Prunus tomentosa and Nicotiana benthamiana hosts by grafting and mechanical inoculation, respectively. Symptoms were evaluated by following the appearance of circular necrotic spots and mosaic in leaves of $P$. tomentosa and mosaic and some leaf deformation in N. benthamiana. Molecular analysis was carried out using reverse transcription-polymerase chain reaction, allowing the cloning and sequencing of 1.34-kb fragments corresponding to the $3^{\prime}$ region of the replicase gene, the complete coat protein (CP) gene, and the $3^{\prime}$ nontranslated region of the PPV genome. Evolutionary distance analysis of these nucleotide sequences and their deduced coat protein amino acid sequences grouped the six Chilean isolates among strain D isolates, with closest genetic distances to those of Central Germany and Poland. Representative sources of these isolates suggest that strain D could be the only type of PPV currently present in Chile.
\end{abstract}

Additional keywords: Potyviridae, Sharka disease, ssRNA

Plum pox virus (PPV), a member of the genus Potyvirus, was initially restricted to Europe $(9,20,21,34,41)$ and North Africa (25), but recent surveys have demonstrated its presence in Adams County, Pennsylvania, in the United States (18), and in some orchards in Ontario and Nova Scotia, Canada. In 1992, PPV was detected in Chile in an apricot orchard in trees exhibiting typical symptoms of Sharka disease (1), the common name of the disease. The presence of PPV was demonstrated by enzyme-linked immunosorbent assay (ELISA) performed on vegetative material from an experimental substation of the Agricultural Research National Institute (Instituto de Investigaciones Agropecuarias, INIA) in the central zone of Chile, the main growing area for stone fruits.

The numerous PPV isolates described to date have been classified into four major groups: Marcus (M), Dideron (D), El Amar

Corresponding author: H. Prieto

E-mail: hprieto@platina.inia.cl

Accession numbers: AF440741, AF440742, AF740443, AF440744, AF440745, and AF740446.

Accepted for publication 2 August 2002.

Publication no. D-2002-1111-01R

(c) 2003 The American Phytopathological Society
(EA), and Cherry (C) $(5,8,29,31)$. M strain isolates cause more severe symptoms than D strain isolates (10). Within a specific isolate belonging to a particular PPV strain, different pathogenicity determinants can be found, which influence the final symptomatology in the infected host (36). Previous molecular studies carried out in Chile confirmed the presence of PPV (35) on the basis of positive amplification of a 222-bp fragment, corresponding to the $3^{\prime}$ noncoding region (NCR) of the viral genome as described by Levy and Hadidi (19). Such results were reinforced using an additional set of primers that amplified 243 bp of the $3^{\prime}$ end of the coat protein (CP) gene $\left(3^{\prime}-\mathrm{CP}\right)(44)$. Preliminary sequencing of these $3^{\prime}$-CP clones demonstrated that conserved $A l u \mathrm{I}$ and $R s a \mathrm{I}$ restriction sites were present in this zone, with nucleotide similarities ranging from 93 to $98 \%$ equivalent genomic portion to PPV strain D (PPV-D) isolates (35). Unfortunately, these findings were obtained using field samples from very specific orchards in the central area of the country, and differences between lengths of $3^{\prime}$-CP fragments were seen after sequencing. At the present time, these are the unique molecular data available for design management strategies of Sharka disease in Chile (26). We describe the isolation of six isolates in the central Chilean valley where PPV has been detected in routine surveys, symptom evaluation of these isolates on woody and herbaceous hosts, and their partial characterization using sequence analysis of NCR, $\mathrm{CP}$, and the replicase $(\mathrm{NIb})$ genes.

\section{MATERIALS AND METHODS}

Indexing on Prunus tomentosa. P. tomentosa hybrid IR473 $\times$ IR474 seedlings (obtained from certified, virus-free seeds from Washington State University-Prosser NRSP5) were used as indexing hosts. Three-month-old plants were inoculated by grafting three bark chips collected from material showing Sharka disease symptoms and positive ELISA readings. Three seedlings were inoculated for each isolate. Bark chips from healthy seedlings of peach GF-305 were used as negative controls. Inoculated plants were maintained in a greenhouse at $22^{\circ} \mathrm{C}$ with a 16 -h photoperiod. One week after inoculation, seedlings were cut back to $2 \mathrm{~cm}$ above the highest inoculum bud-graft to promote the development of new leaves, and the remaining leaves were eliminated as described by Damsteegt et al. (11).

Mechanical transfer to Nicotiana benthamiana. $N$. benthamiana seeds were sown in small pots and maintained at $28^{\circ} \mathrm{C}$ for 3 to 4 weeks. Seedlings were moved to individual pots, and 1 to 2 weeks later (or when they had four true leaves), they were inoculated with leaf extracts from $P$. tomentosa that showed Sharka-like symptoms and that were also ELISA positive for PPV. Five different trials were carried out for each virus isolate. Leaf extracts from healthy GF-305-inoculated $P$. tomentosa plants were used as negative controls as described by Sáenz et al. (37). Extracts were obtained by macerating leaves in phosphate buffer (PBS) $\left(0.02 \mathrm{M} \mathrm{KH}_{2} \mathrm{PO}_{4}\right.$, $0.02 \mathrm{M} \mathrm{Na}_{2} \mathrm{HPO}_{4}, 0.5 \%$ diethyldithiocarbamic acid, $\mathrm{pH}$ 7.2) supplemented with $2.5 \%$ nicotine. Celite dust was spread on target leaves, and the leaves were rubbed gently with cotton rods previously imbibed with leaf extracts. After inoculation, leaves were washed with distilled water. Inoculated plants were maintained at $22^{\circ} \mathrm{C}$ with a 16-h photoperiod until symptoms appeared. Inoculated plants were tested by ELISA for the presence of PPV.

ELISA. Polyclonal antibodies against PPV and positive controls were obtained from Bioreba (Bioreba-AG, BL1, Chr. 
Merian-Ring 7, Reinach, Switzerland), and double antibody sandwich-ELISA was performed as previously described (7). Samples were ground 1:10 (wt/vol) in coating buffer (according to the manufacturer's instructions), and $200 \mu \mathrm{l}$ was incubated overnight at $4{ }^{\circ} \mathrm{C}$. Antiserum incubations were done in the presence of PBS-T with $2 \%$ ovalbumin for $3 \mathrm{~h}$ at $37^{\circ} \mathrm{C}$. Samples were considered positive if the absorbance at $405 \mathrm{~nm}$ was twice the average value for samples from healthy controls after $2 \mathrm{~h}$ of reaction with $p$-nitrophenyl phosphate at $1 \mathrm{mg} / \mathrm{ml}$ in substrate buffer $(9.7 \%$ [vol/vol] diethanolamine, $0.20 \mathrm{~g}$ $\mathrm{NaN}_{3}$ per liter, $\mathrm{pH}$ 9.8).

Silica column reverse transcriptionpolymerase chain reaction (RT-PCR). Viral RNA extraction. Total nucleic acid was extracted from infected leaves by silica column extraction as was described previously $(22,24)$ using $0.2 \mathrm{~g}$ of plant tissue. Total nucleic acids were collected and stored at $-70^{\circ} \mathrm{C}$ until use.

$R T$. For single-strand cDNA (ss cDNA) synthesis, $15 \mu$ of total nucleic acids extracted from leaves was mixed with $1 \mu \mathrm{l}$ of a random primers mix $(0.5 \mu \mathrm{g} / \mu \mathrm{l})$ and 7.5 $\mu \mathrm{l}$ of diethylpyrocarbonate-treated water. Nucleic acids were denatured for $3 \mathrm{~min}$ at $95^{\circ} \mathrm{C}$, and then $6 \mu \mathrm{l}$ of $5 \times \mathrm{RT}$ buffer (Promega, Madison, WI) and $0.5 \mu \mathrm{l}$ of RNasin (40 U/ $\mu$ l, Promega) were added. This mixture was annealed for $15 \mathrm{~min}$ at room temperature, and then $5 \mu \mathrm{l}$ of $0.3 \mathrm{M}$ $\beta$-mercaptoethanol, $2.5 \mu \mathrm{l}$ of $10 \mathrm{mM}$ dNTPs, 200 units of M-MLV reverse tran- scriptase (Promega), and water to a final volume of $50 \mu \mathrm{l}$ were added. The RT reaction was carried out at $39^{\circ} \mathrm{C}$ for $70 \mathrm{~min}$. After incubation, the cDNA mixture was kept on ice until PCR.

PCR. Specific primers were designed with Oligo version 5.0 software (National Biosciences, Inc., Plymouth, MN), using partial PPV sequences selected and analyzed from public domain databases (17,23,43). The designed primers, PPV8413 (forward primer): 5' ACA ATG CTC TTT CAA AAG ATG GAA 3' and PPVC (19) (reverse primer): 5' GTC TCT TGC ACA AGA ACT ATA ACC 3' (synthesized by Integrated DNA Technologies, Coralville, IA), amplified a region of 1,374 bases of the $3^{\prime}$ region of the viral genome, corresponding to the $3^{\prime}$ end of the $\mathrm{NIb}, \mathrm{CP}$, and NCR.

For the amplification reaction, ss cDNA was used as a template for the specific PCR using Pfu DNA polymerase (GibcoBRL, Rockville, MD), PPV8413, and PPVC primers, with an amplification profile of 35 cycles of $1 \mathrm{~min}$ at $94^{\circ} \mathrm{C}, 1 \mathrm{~min}$ at $55^{\circ} \mathrm{C}$, and $1.5 \mathrm{~min}$ at $72^{\circ} \mathrm{C}$. The amplified fragment was purified using Wizard-PCR columns (Promega) and then ligated into plasmid pGEM-T (Promega). PPV recombinant clones were sequenced using an ABI-Prism 310 machine (Applied Biosystems, Foster City, CA).

Sequences. Sequences used for primer design, nucleotide, and deduced amino acid comparisons among Chilean isolates and PPV strain D isolates are given in

Table 1. Plum pox virus sequences used for comparisons of Chilean isolates

\begin{tabular}{|c|c|c|c|}
\hline Author -isolate & Accession no. & Strain & Ref. \\
\hline Nemchinov $(a, b)^{y}$ & X97398 & $\mathrm{C}$ & 30 \\
\hline Wetzel $(a, b)$ & X56258 & EA & 43 \\
\hline Cervera $(a, b)$ & S57405 & M & 6 \\
\hline Glasa $(a, b)$ & AY028309 & M & 14 \\
\hline Sáenz $(a, b)$ & AJ242957 & M & 36 \\
\hline Salamon $(a, b)$ & AJ306420 & M & $(-)^{\mathrm{Z}}$ \\
\hline Asensio-NAT & AF172347 & $\mathrm{D}$ & $(-)$ \\
\hline Asensio-RB/GF & AF172346 & $\mathrm{D}$ & $(-)$ \\
\hline Asensio-RB/GF13 & AF172350 & $\mathrm{D}$ & $(-)$ \\
\hline Asensio-RB/GF15 & AF172348 & $\mathrm{D}$ & $(-)$ \\
\hline Deborré-AL (b) & X81078 & $\mathrm{D}$ & 13 \\
\hline Deborré-DOH1 (b) & X81084 & $\mathrm{D}$ & 13 \\
\hline Deborré-GSP (b) & X81080 & $\mathrm{D}$ & 13 \\
\hline Deborré-HB (b) & X81076 & $\mathrm{D}$ & 13 \\
\hline Deborré-LI (b) & X81081 & $\mathrm{D}$ & 13 \\
\hline Deborré-NEB (b) & X81075 & $\mathrm{D}$ & 13 \\
\hline Deborré-NL (b) & X81074 & $\mathrm{D}$ & 13 \\
\hline Deborré-OB1 & X81077 & $\mathrm{D}$ & 13 \\
\hline Deborré-SH (b) & X81073 & $\mathrm{D}$ & 13 \\
\hline Deborré-SL & X81079 & $\mathrm{D}$ & 13 \\
\hline Laín (a,b) & M21847 & $\mathrm{D}$ & 17 \\
\hline Maiss-AT (b) & X57975 & $\mathrm{D}$ & $(-)$ \\
\hline Maiss-CG (a,b) & X81083 & $\mathrm{D}$ & $(-)$ \\
\hline Maiss-NAT $(a, b)$ & NC_001445 & $\mathrm{D}$ & $(-)$ \\
\hline Malinowski & AF332871 & $\mathrm{D}$ & $(-)$ \\
\hline Palkovics & AJ000340 & $\mathrm{D}$ & $(-)$ \\
\hline Ravelonandro (b) & D00298 & $\mathrm{D}$ & 33 \\
\hline Teycheney $(\mathrm{a}, \mathrm{b})$ & X16415 & $\mathrm{D}$ & 42 \\
\hline Wypijewski & $\mathrm{U} 27652$ & $\mathrm{D}$ & 46 \\
\hline
\end{tabular}

$\mathrm{y}$ (a), sequence used for interstrain comparison in addition to the Chilean isolates. (b), sequence used for 3' noncoding region analysis.

${ }^{\mathrm{z}}$ Sequence directly submitted to EMBL.
Table 1. Sequences used for general comparison among Chilean isolates and different PPV strains are showed in Table 1 and marked with (a). Translation of sequences was carried out using the Translate tool of PCGene release 6.60 package (University of Geneva, Switzerland).

Statistical analysis of sequences. The nucleotide sequences of the Chilean PPV isolates were compared using Basic Local Alignment Search Tool (BLAST) (2) at the National Center for Biotechnology Information (4). Local PPV sequences and EMBL (40) sequences derived from the matching process were selected and then compared using NALIGN and alignment method of PCGene release 6.60 for determination of similarity percentages (27) and using Clustal W (1.6) from Omiga 2.0 (Oxford Molecular Ltd., The Molecular Center, Oxford Science Park, Oxford, UK) for single clustering of sequences (45). For preliminary similarity comparison among Chilean isolates and 10 different isolates corresponding to different PPV strains, 1,374 bases were computed for a genetic distance matrix using DNAdist from Phylip package, version 3.6 (alpha) (University of Washington, Seattle), using the Kimura "2-parameter" method (16). The distance matrix was evaluated for successive clustering using the Neighbor-Joining component of the same package (38). To calculate genetic distances between PPV strain D isolates, the sequences' corresponding CP genes for the 6 Chilean and 23 PPV-D isolates were analyzed using the same methods as above. These sequences were additionally used for determination of protein evolutionary distances. Deduced sequences were compared using the percent accepted mutation (PAM) method (12) from the Phylip package. Protein sequences were obtained using the translation option from Omiga 2.0 software.

\section{RESULTS}

Symptoms on $P$. tomentosa and $N$. benthamiana hosts produced by PPV isolates. Several routine surveys carried out on commercial orchards during the November 1999-January 2000 growing season identified six infected Prunus sp. trees with Sharka disease symptoms. Isolates 12 (from Marianna), 20 (from GF677), and 112 (from peach) were located in Rancagua ( $34^{\circ} 10^{\prime} \mathrm{S}, 70^{\circ} 45^{\prime} \mathrm{W}$ ); isolates 114 (from apricot) and 116 (from plum) were located in Buín $\left(33^{\circ} 40^{\prime} \mathrm{S}\right.$, $70^{\circ} 45^{\prime} \mathrm{W}$ ); and isolate 31 (from peach) was located in San Felipe $\left(32^{\circ} 45^{\prime} \mathrm{S}\right.$, $70^{\circ} 30^{\prime} \mathrm{W}$ ) (Fig. 1).

Shoots from these trees were grafted onto $P$. tomentosa during the December 1999/February 2000 period. At budding, in September 2000, circular spots and foliar mosaic and vein yellowing were observed in all of the graft-inoculated $P$. tomentosa plants (Fig. 2). Positive PPV ELISA results (absorbance values ranging between 2.124 
and 2.767) correlated with the appearance of these symptoms, whose expression pattern was similar among trees infected with different PPV isolates. No other Prunus viruses or phytoplasma could be detected using specific ELISA or specific PCR molecular analysis. These tests included ELISA for Prunus necrotic ringspot virus, Prune dwarf virus, Tomato ringspot virus, Apple chlorotic leaf spot virus, Raspberry ringspot virus, Strawberry latent ringspot virus, Cherry leaf roll virus, Tobacco streak virus, and PCR detection for Peach western X phytoplasma (39), and Aster yellows phytoplasma (15).

P. tomentosa infected with these PPV isolates was used for mechanical inoculation of the herbaceous host $N$. benthamiana. Approximately 25 days after inoculation, Nicotiana plants began to show symptoms of mosaic and some vein clearing (Fig. 2 insert). These infected N. benthamiana plants were evaluated for the presence of other viruses or phytoplasma as above, but were negative in these tests (data not shown).

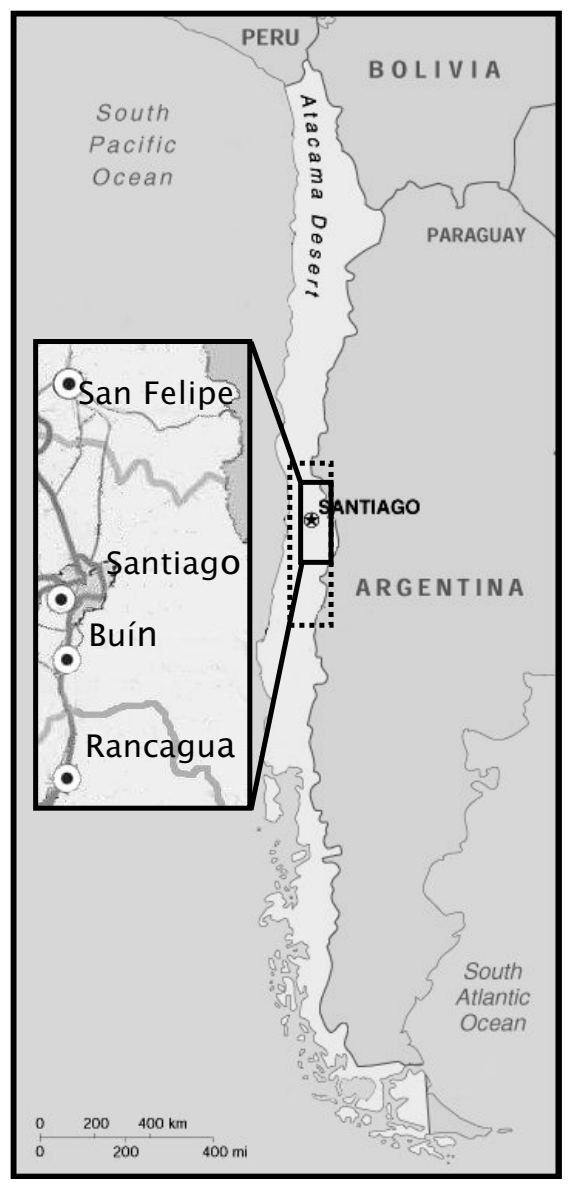

Fig 1. Location of different zones selected for sampling of Sharka disease symptomatic trees. Dashed-line rectangle shows the main stone fruit growing area in Chile. Detail shows four different locations specifically sampled: San Felipe $\left(32^{\circ} 45^{\prime} \mathrm{S}, 70^{\circ} 30^{\prime} \mathrm{W}\right)$, Santiago $\left(33^{\circ} 23^{\prime} \mathrm{S}, 70^{\circ} 45^{\prime} \mathrm{W}\right)$, Buín $\left(33^{\circ} 40^{\prime}\right.$ $\left.\mathrm{S}, 70^{\circ} 45^{\prime} \mathrm{W}\right)$, and Rancagua $\left(34^{\circ} 10^{\prime} \mathrm{S}\right.$, $\left.70^{\circ} 45^{\prime} \mathrm{W}\right)$. Scale in kilometers $(\mathrm{km})$ and miles (mi) is shown.
Sequence of $3^{\prime}$ end of the PPV genome and similarity analysis. Cloning and sequencing of the $3^{\prime}$ end of the PPV genome for these six Chilean isolates permitted their confirmation as PPV strain D. Sequence analysis of each isolate demonstrated the presence of both an $R s a \mathrm{I}$ and an AluI restriction site, as described for PPV$\mathrm{D}$ isolates $(13,32,44)$. Pairwise alignment percentage identities using Clustal W (1.60) analysis showed that similarities among the Chilean isolates ranged from 98 to $99 \%$, grouping isolate 112 (accession no. AF440741) with isolate 12 (AF440744), isolate 114 (AF440742) with isolate 20 (AF440745), and isolate 116 (AF440743) with isolate 31 (AF440746). When published PPV strain sequences (Table 1, "a" tagged sequences) corresponding to the same genomic region of 1,374 nucleotides at $3^{\prime}$-terminal end were included in this similarity analysis, Chilean isolates were grouped in the same branch as those isolates described as belonging to the PPV-D strain (Fig. 3). When only NCR sequences were used in this analysis (Table 1 , "b" tagged sequences), identical results were obtained in terms of grouping Chilean isolates inside of the strain D cluster (not shown).

To determine any differences among the Chilean D isolates, a more exhaustive sequence analysis including 23 PPV-D CP gene sequences (Table 1, all strain D sequences) was done. Genetic distances established in this way showed a close relationship between Chilean isolates 12 and 112 with the German isolates DeborréDOH1, Deborré-SH, Deborré-HB, and Deborré-NEB (Fig. 4). On the other hand, isolates 20 and 114 were grouped with two Polish isolates (Malinowski-AIN and Wypijewski-Skierniewice). This group was positioned very close to the one constituted

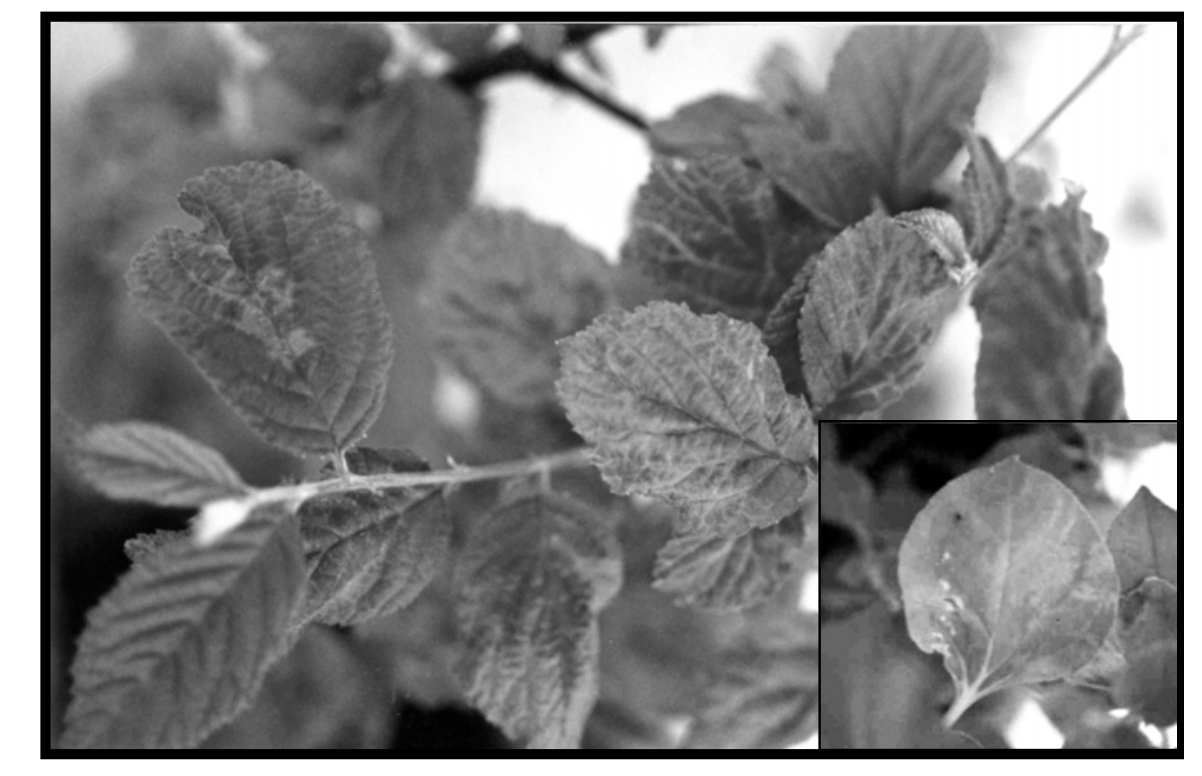

Fig 2. Leaf symptoms observed in infected Prunus tomentosa plants (woody hosts) grafted with shoots from selected fields. Symptoms in Nicotiana benthamiana plants (herbaceous hosts) 25 days after mechanical inoculation using these woody hosts are shown in the insert. by the Chilean isolate 116 and the Central Germany isolate Deborré-OB1. Finally, the isolate designated as 31 was shown to be close to two PPV isolates reported as strain D from France by Ravelonandro et al. (33) and Teycheney et al. (42) (Fig. 4). Comparison of only NCR sequences showed again three groups in which the Chilean isolates distributed close to the French and Central Germany isolates (not shown). Isolates 116 and 31 maintained their proximity to the French isolates, and isolates $12,20,112$, and 114 were very close to the German isolates described by Deborré (13) and by Maiss et al. (Maiss-AT isolate) (23). In this tree, isolates 20 and 114 were very close (not shown).

Amino acid sequences from the $\mathrm{CP}$ genes were obtained using translation tool from OMIGA 2.0 and then compared. Analysis by Clustal W (1.60) reinforced the strong similarity among Chilean isolates, ranging from 97 to $98 \%$. A more exhaustive analysis, including all of PPV$\mathrm{D}$ deduced CP portions using the PAM method and then neighbor-joining analysis, demonstrated that Chilean isolates were split into three groups (Fig. 5). One group consisted of isolates 12,112 , and 31 , which was most similar to isolates from Central Germany (Deborré-AL, Deborré-SH, and Deborré-DOH1), to isolates from Poland (Malinowski-AIN, Wypijewski-Skierniewice), and to the isolate Asensio-RB/GF15. Isolates 114 and 20 were located in a different branch, but with some relationship to the first one. This second group included, close to the Chilean isolates, the non-aphidtransmissible (NAT) Maiss-NAT isolate (23) and, at greater distance, Maiss-CG, Laín, and Deborré-NL isolates. Isolate 116 was positioned in a completely different location on this evolutionary dis- 


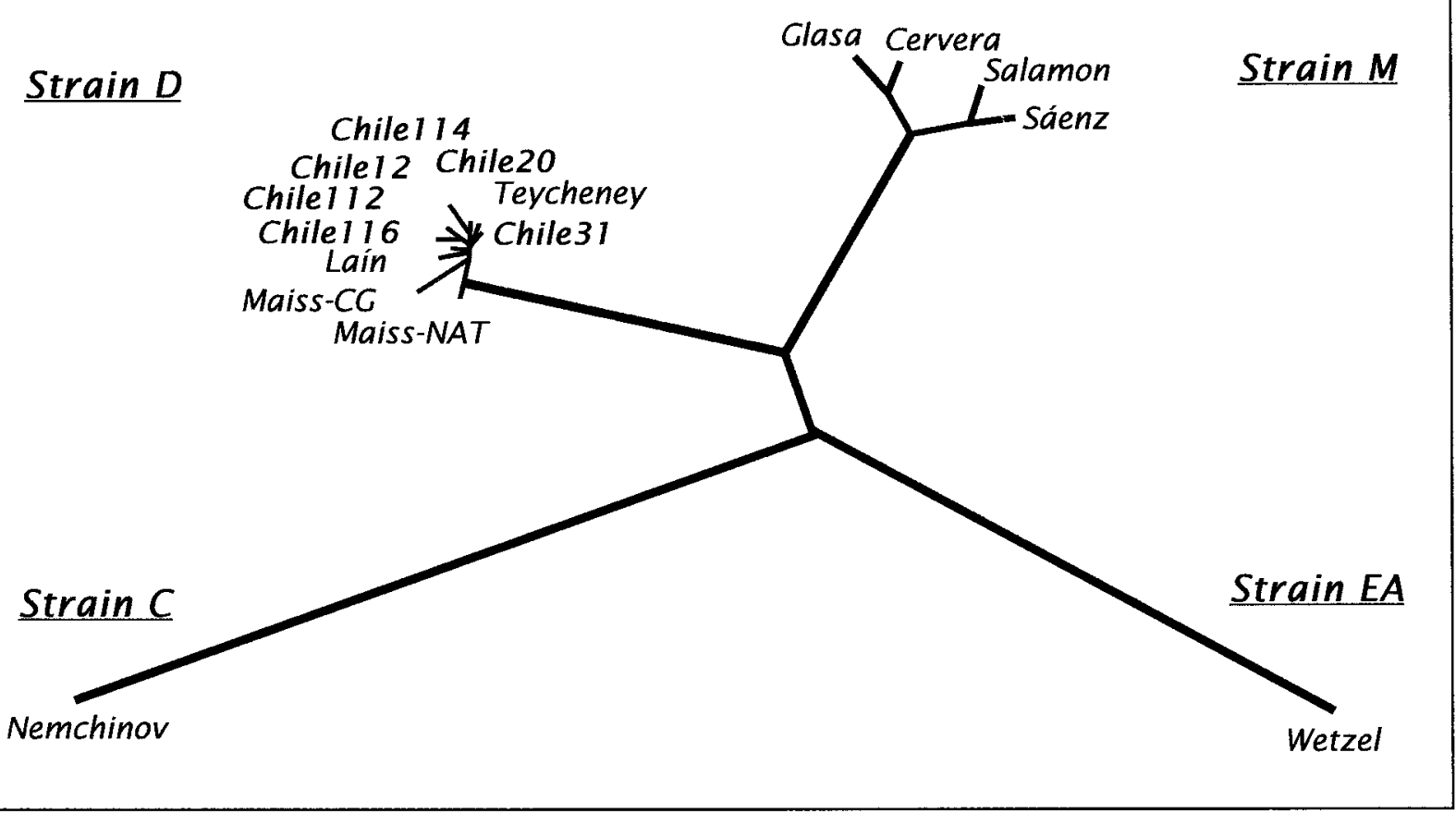

Fig 3. Phenogram of similarity among the four Plum pox virus (PPV) strains including the six Chilean isolates. D, PPV strain D; M, PPV strain M; EA, PPV strain El Amar; and C, PPV strain Sour Cherry. Nonrooted tree was constructed analyzing 3' genomic ends of viral ssRNAs by Kimura's two parameters and neighbor-joining method. Sequence keys correspond to the same listed in Table 1 and marked with (a).

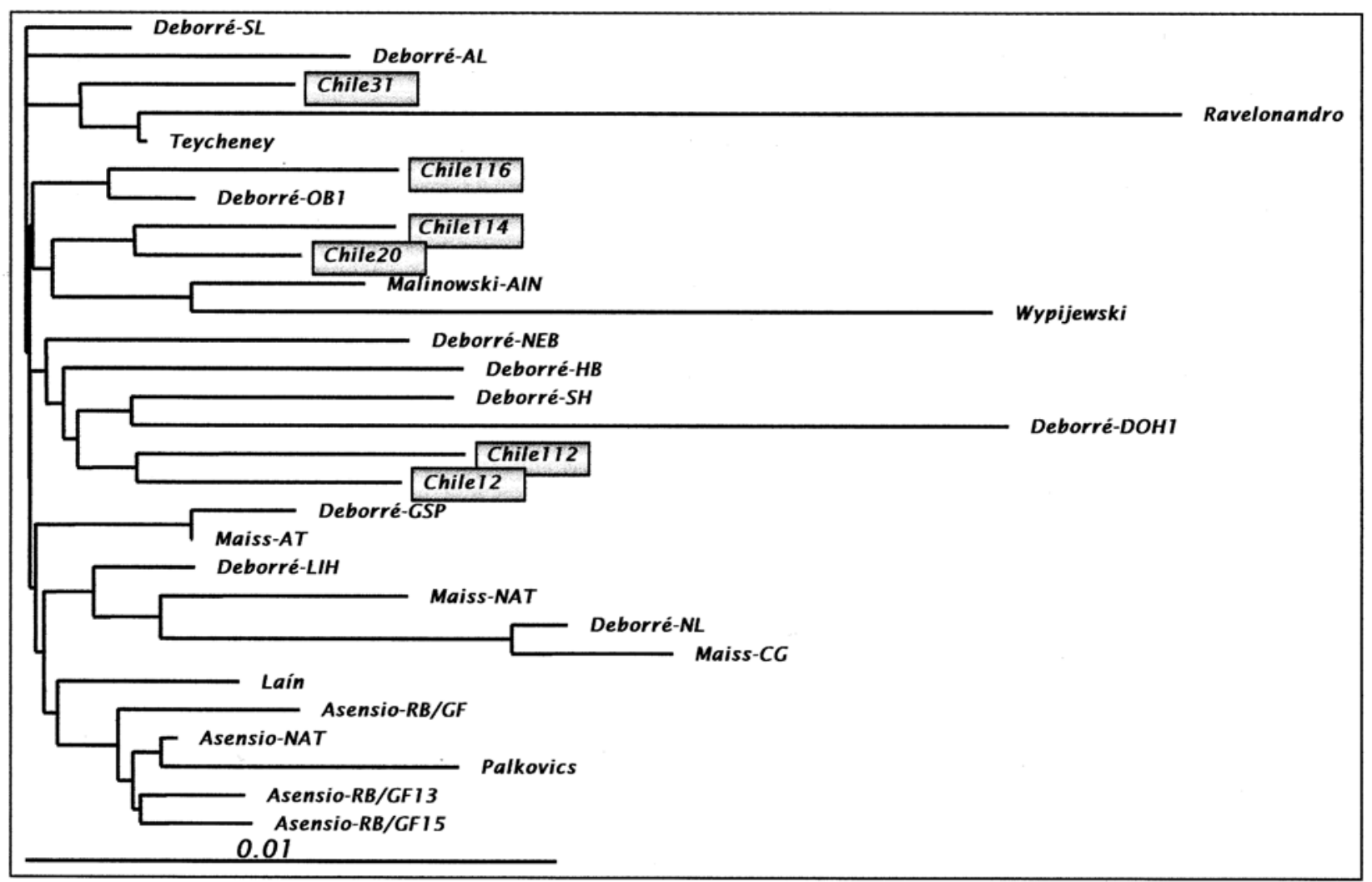

Fig 4. Genetic distances for nucleotide $3^{\prime}$ end sequences of Plum pox virus (PPV) strain D genomes and the six PPV Chilean isolates. 1,374 bp from 23 previously reported isolates $3^{\prime}$-end genomic PPV strain D sequences were compared with corresponding sequences of the six Chilean isolates. Analysis was carried out using the Kimura's two parameters and neighbor-joining method. Sequences are the same listed in Table 1. Chile 12 (AF440744), 20 (AF440745), 31 (AF440746), 112 (AF440741), 114 (AF440742), and 116 (AF440743), PPV Chilean isolates. 
tances tree, close to the German PPV isolate Deborré-OB1 (Fig. 5).

\section{DISCUSSION}

The results described here indicate that all the Chilean PPV isolates evaluated belong to strain D. No differences in symptoms or severity of infection were observed either in $P$. tomentosa or in $N$. benthamiana. All of the symptoms observed could be attributed exclusively to PPV infection, as no other Prunus-related pathogens were detected in the woody and herbaceous hosts. Currently, we have no information about the behavior of these six isolates in other herbaceous hosts such as Chenopodium foetidum, which is a useful indicator for the biological characterization of PPV (13).

Considering that the six isolates used in this study came from different areas corresponding to geographical zones where PPV-D has been identified in routine surveys carried out by the National Phytosanitary Service (26), the conclusions from symptoms, general serological screening, and sequence analysis of the cloned $3^{\prime}$ end of their genomes, suggest that the main type of PPV present in the stone fruit growing area of Chile is strain D. Although the Chilean PPV isolates appear closely related to those described in Central Europe, we cannot explain how this strain of PPV became distributed in the different geographical locations in Chile.
A high degree of similarity was observed at the nucleotide level among different Chilean isolates, which was maintained when additional PPV-D sequences were incorporated in the analysis (Fig. 4). The Chilean isolates were distributed within D branches when analyzed together with different PPV strains, such as PPV-M, PPV-Sc, and PPVEl Amar (Fig. 3). Within the D cluster, in general terms of genetic distances, Chilean isolates were close to isolates described for Central Germany (in the cases of isolates 12, 112 , and 116), for Poland (in the case of isolates 20,31, and 114), and to one isolate described as D, which has been propagated in pea var. Express Genereux in France (33) (Fig. 4). These results were reinforced when NCR sequences were scored (not shown), although in such analysis it was not possible to include all the isolates because there are few available sequences of this genomic zone for them (Table 1, "b" tagged sequences).

In agreement with some previously reported data (32,33), amino-terminaldeduced sequences of $\mathrm{CP}$ are the main source of variability, while the carboxyterminal region is highly conserved, indicating that the $\mathrm{C}$-terminal region of the $\mathrm{CP}$ is a core region (32). The proposed proteolytic site for processing of the polyprotein at the level of the NIb-CP region (specific Q-A residues) (23), and the aphid transmission motif (conserved DAG residues of CP) (3), were present in all of the six Chil- ean PPV isolates (not shown). However, Clustal or PAM/neighbor-joining comparisons, similarity, and evolutionary distances analysis showed that NAT isolates can be assigned to any part of the tree (even close to Chilean isolates 114 and 20), regardless of the absence of the N-terminal motif of the $\mathrm{CP}$ containing the DAG triplet. The presence of NAT isolates in Chile remains to be determined, and transmissibility of isolates reported here remains to be assayed.

The presented data, together with the other available sequences, provide useful information concerning PPV isolates found in Chile. These findings may be particularly relevant in light of recent reports of the presence of PPV in North America. A more exhaustive analysis of pathogenicity determinants and vectors present in the same surveyed area should be carried out, considering that all of the isolates had the motif responsible for aphid transmission. A more detailed analysis using some additional monoclonal antibodies recently developed (28) is currently in progress, and sequence-homology-dependent protection assays using transgenic $N$. benthamiana plants with $\mathrm{CP}$ and NIb genes are being carried out, in attempts to establish additional differences among these isolates.

\section{ACKNOWLEDGMENTS}

We thank Ralph Scorza (USDA-AFRS), Laurene Levy (USDA-APHIS), and Arben Myrta

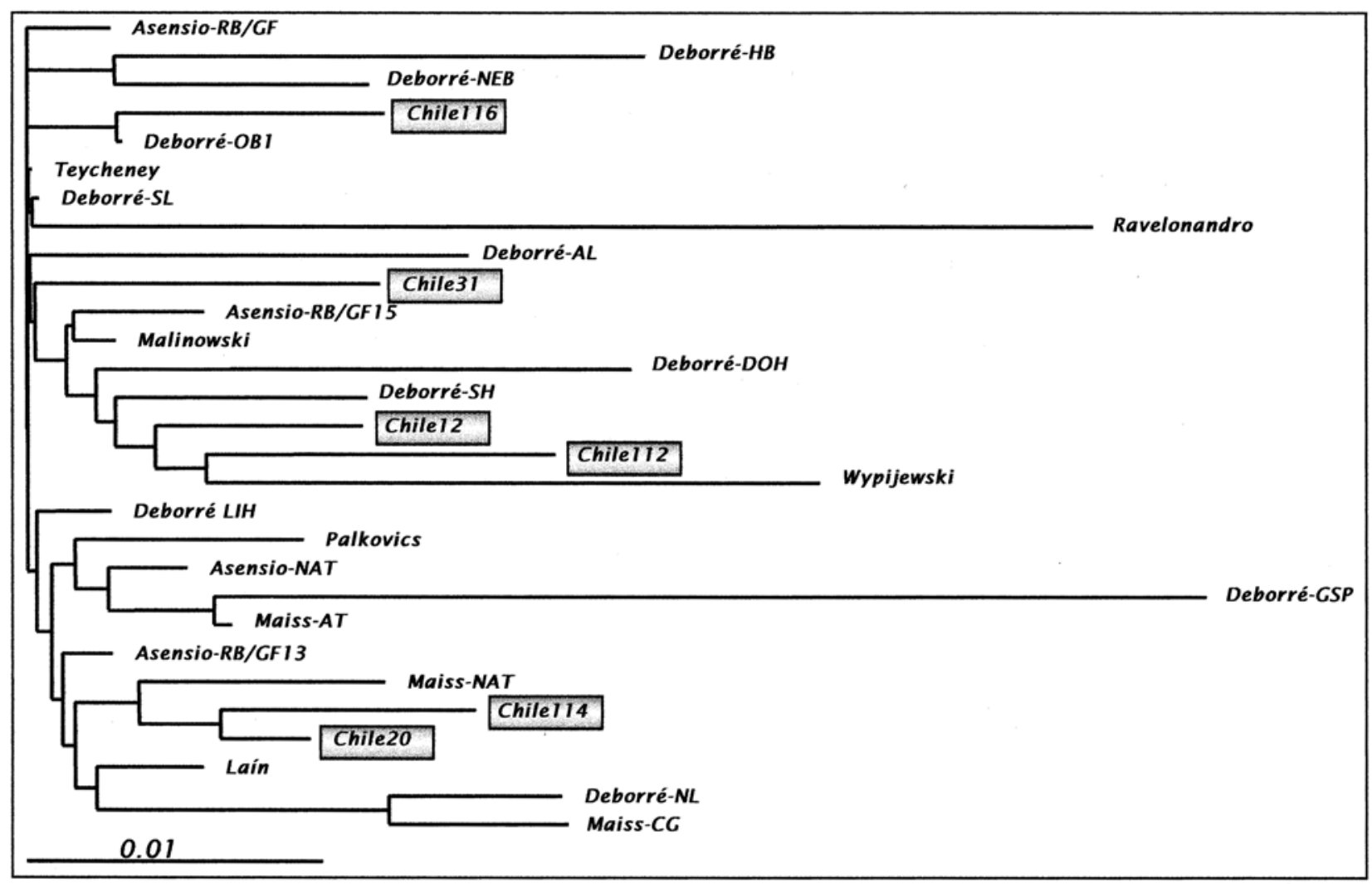

Fig 5. Evolutionary distances for deduced coat protein sequences of Plum pox virus strain D (PPV-D) and the six Chilean isolates. Analysis was carried out using the percent accepted mutation method and neighbor-joining. Symbols are the same as indicated in Figure 4. 
(IAM-BA-IT) for critical review of the manuscript and continuous support to this working group. We also thank Mike Moynihan for linguistic revision of the manuscript, and Juan Antonio Garcia's laboratory (Centro Nacional de Biotecnología, Spain) for automatic DNA sequencing. This work was mainly supported by project FONDECYTChile 1990207. Also, projects FONDEF-Chile D97I2030 and FIA-Chile F01-1-BT-027 permitted us to carry out several tasks of this study.

\section{LITERATURE CITED}

1. Acuña, R. 1993. Outbreaks of plum pox virus in Chile. Eur. Mediterr. Plant Prot. Org. Conf. Plum pox virus, August 5-8, Bordeaux, France.

2. Altschul, S., Gish, W., Miller, W., Myers, E., and Lipman, D. 1990. Basic local alignment search tool. J. Mol. Biol. 215:403-410.

3. Atreya, C., Raccah, B., and Pirone, T. 1990. A point mutation in the coat protein abolishes aphid transmissibility of a potyvirus. Virology 178:161-175.

4. Benson, D., Karsch-Mizrachi, I., Lipman, D., Ostell, J., Rapp, B., and Wheeler, D. 1999. GenBank. Nucleic Acids Res. 27:12-17.

5. Candresse, T., Cambra, M., Dallot, S., Lanneau, M., Asensio, M., Gorris, M. T., Revers, F., Macquaire, G., Olmos, A., Boscia, D., Quiot, J. B., and Dunez, J. 1998. Comparison of monoclonal antibodies and polymerase chain reaction assays for the typing of isolates belonging to the $\mathrm{D}$ and $\mathrm{M}$ serotypes of plum pox potyvirus. Phytopathology 88:198-204.

6. Cervera, M., Riechmann, J., Matín, M., and García, J. 1993. 3' terminal sequence of plum pox virus PS and o6 isolates: Evidence for RNA recombination within potyvirus group. J. Gen. Virol. 74:329-334.

7. Clark, M., and Adams, A. 1977. Characteristics of the microplate method of enzymelinked immunosorbent assay for the detection of plant viruses. J. Gen. Virol. 34:475-483.

8. Crescenzi, A., d'Aquino, L., Comes, S., Nuzzaci, M., Piazzolla, P., Boscia, D., and Hadidi, A. 1997. Characterization of the sweet cherry isolate of plum pox potyvirus. Plant Dis. 81:711-714.

9. Cropley, R. 1968. The identification of plum pox (Sharka) virus in England. Plant Pathol. 17:66-70.

10. Dallot, S., Labonne, G., Boeglin, M., QuiotDouine, L., Quiot, J., and Candresse, T. 1998. Peculiar plum pox potyvirus D-populations are epidemic in peach trees. Acta Hortic. 472:355-365.

11. Damsteegt, V. D., Waterworth, H. E., Mink, G. I., Howell, W. E., and Levy, L. 1997. Prunus tomentosa as a diagnostic host for detection of plum pox virus and other Prunus viruses. Plant Dis. 81:329-332.

12. Dayhoff, M., Schwartz, R., and Orcutt, B. 1978. A model of evolutionary change in protein. Matrices for detecting distant relationships. Pages 345-358 in: Atlas of Protein Sequence and Structure, vol. 5. M. Dayhoff, ed. National Biomedical Research Foundation, Washington, DC.

13. Deborré, G., Jelkman, W., and Maiss, E. 1995. Biological and molecular investigation of several plum pox virus (PPV) isolates. Acta Hortic. 386:253-262.

14. Glasa, M., Kudela, O., Marie-Jeanne, V., and Quiot, J. B. 2001. Evidence of a naturally occurring recombinant isolate of plum pox virus rom Slovakia. Plant Dis. 85:920.

15. Khadhair, A., Tewari, J., Howard, R., and Paul, V. 2001. Detection of aster yellows phytoplasma in false flax based on PCR and RFLP. Microbiol. Res. 156:179-184.

16. Kimura, M. 1980. A simple method for estimating evolutionary rates of base substitutions through comparative studies of nucleotide sequences. J. Mol. Evol. 16:111-120.

17. Laín, S., Riechmann, J., Méndez, E., and García, J. 1988. Nucleotide sequence of the $3^{\prime}$ terminal region of plum pox potyvirus RNA. Virus Res. 10:325-342.

18. Levy, L., Damsteegt, V., Mavrodieva, V., Goley, E., Welliver, R., and Luster, D. 2000. Identification of plum pox potyvirus in the United States. XVIII Int. Sympos. Virus Virus-like Dis. Temperate Fruit Crops. July 915, Canterbury, England.

19. Levy, L., and Hadidi, H. 1994. A simple and rapid method for processing tissue infected with plum pox virus potyvirus for use with specific $3^{\prime}$ non-coding region RT-PCR assays. OEPP/EPPO Bull. 24:595-604.

20. Llácer, G., Cambra, M., Lavina, A., and Arambur, J. 1986. Investigations on plum pox (sharka) virus in Spain. Acta Hortic. 193:155159.

21. Louro, D., and Corvo, L. 1986. Occurrence of sharka in Portugal. Acta Hortic. 193:183-186.

22. MacKenzie, D. J., McLean, M. A., Mukerji, S., and Green, M. 1997. Improved RNA extraction from woody plants for the detection of viral pathogens by reverse transcription-polymerase chain reaction. Plant Dis. 81:222-226.

23. Maiss, E., Timpe, U., Brisske, A., Jelkmann, W., Casper, R., Himmler, G., Mattanovich, D., and Katinger, H. 1989. The complete nucleotide sequence of plum pox virus RNA. J. Gen. Virol. 70:513-524.

24. Malinowski, T. 1997. Silica capture-reverse transcription-polymerase chain reaction (SCRT-PCR): Application for detection of several plant viruses. Pages 445-448 in: Diagnosis and Identification of Plant Pathogens. H. W. Dehne, ed. Kluwer Academic Publishers, Dordrecht, The Netherlands.

25. Mazyad, H. M., Nakhla, M. K., and Abo-Elea, A. 1992. Occurrence of plum pox (Sharka) virus on stone fruit trees in Egypt. Acta Hortic. 309:119-124

26. Muñoz, M. 2001. Resultados del control obligatorio y seguimiento fitosanitario de Plum pox virus (PPV) durante el período 1995-1999. Simiente (Chile) 71:33

27. Myers, E., and Miller, W. 1988. Optimal alignments in linear space. Comput. Appl. Biosci. 4:11-17.

28. Myrta, A., Di Terlizzi, B., Boscia, D., Çaglayan, K., Gavriel, I., Ghanem, G., Varveri, C., and Savino, V. 1998. Detection and serotyping of Mediterranean plum pox virus isolates by means of strain-specific monoclonal antibodies. Acta Virol. 42:251-253.

29. Myrta, A., Potere, O., Crescenzi, A., Nuzzaci, M., and Boscia, D. 2000. Properties of two monoclonal antibodies specific to the cherry strain of plum pox virus. J. Plant Pathol. 82:95-101.

30. Nemchinov, L., Hadidi, A., Maiss, E., Cambra, M., Candresse, T., and Damsteegt, V. 1996. Sour cherry strain of plum pox potyvirus (PPV): Molecular and serological evidence for a new subgroup of PPV strains. Phytopathology 86:1215-1221.
31. Pasquini, G., and Barba, M. 1997. Plum pox potyvirus strains: An overview. Pages 168 171 in: Proc. Middle Eur. Meeting'96 Plum Pox.

32. Ravelonandro, M., Delbos, R., Varveri, C., and Dunez, J. 1988. Capsid protein of plum pox potyvirus: Structure and comparison with that of other potyviruses. Acta Hortic. 235:305-312.

33. Ravelonandro, M., Varveri, C., Delbos, R and Dunez, J. 1988. Nucleotide sequence of capsid protein gene of plum pox potyvirus. J. Gen. Virol. 69:1509-1516.

34. Refatti, E., Osler, R., Loi, N., and Vindimian, E. 1985. Sharka disease in a plum area of Trento province, Italy. Riv. Pathol. Veg. 21:41-49.

35. Rosales, M., Hinrichsen, P., and Herrera, G. 1997. Molecular characterization of plum pox virus isolated from apricots, plums and peaches in Chile. Acta Hortic. 472:401-405.

36. Sáenz, P., Cervera, M., Dallot, S., Quiot, L., and Quiot, J. 2000. Identification of a pathogenic determinant of plum pox virus in the sequence encoding the $\mathrm{C}$-terminal region of protein P3 + 6K. J. Gen. Virol. 81:557-566.

37. Sáenz, P., Quiot, L., Quiot, J., Candresse, T., and García, J. 2001. Pathogenicity determinants in the complex virus population of a Plum pox virus isolate. Mol. Plant-Microb. Interact. 14:278-287.

38. Saitou, N., and Nei, M. 1987. The neighborjoining method: A new method for reconstructing phylogenetic trees. Mol. Biol. Evol. 4:406-425.

39. Smart, C., Schneider, B., Blomquist, C., Guerra, L., Harrison, N., Ahrens, U., Lorenz, K., Seemuller, E., and Kirkpatrick, B. 1996 Phytoplasma-specific PCR primers based on sequences of the $16 \mathrm{~S}-23 \mathrm{~S}$ rRNA spacer region. Appl. Environ. Microbiol. 62:2988 2993.

40. Stoesser, G., Baker, W., van den Broek, A., Camon, E., Garcia-Pastor, M., Kanz, C., Kulikova, T., Leinonen, R., Lin, Q., Lombard, V., Lopez, R., Redaschi, N., Stoehr, P., Tuli, M. A., Tzouvara, K., and Vaughan, R. 2002. The EMBL Nucleotide Sequence Database. Nucleic Acids Res. 30:21-26.

41. Sutic, D., and Pine, T. 1968. Sharka (Plum Pox) disease. Plant Dis. Rep. 52:253-256.

42. Teycheney, P., Tavert, G., Delbos, R., Ravelonandro, M., and Dunez, J. 1989. The complete nucleotide sequence of plum pox virus RNA (strain D). Nucleic Acids Res. 17:1011510116.

43. Wetzel, T., Candresse, T., Ravelonandro, M., Delvos, R., Mazyad, H., Aboul-Ata, A., and Dunez, J. 1991. Nucleotide sequence of the 3 terminal region of the RNA of the El Amar strain of plum pox potyvirus. J. Gen. Virol. 72:1741-1746.

44. Wetzel, T., Candresse, T., Ravelonandro, M. and Dunez, J. 1991. A polymerase chain reaction assay adapted to plum pox potyvirus detection. J. Virol. Methods 33:355-365.

45. Wilbur, W., and Lipman, D. 1983. Rapid similarity searches of nucleic acid protein data banks. Proc. Natl. Acad. Sci. U.S.A 80:726-730.

46. Wypijewski, K., Malinowski, T., Musial, W., and Augustyniak, J. 1994. Nucleotide sequence of the coat protein gene of the Skierniewice isolate of plum pox virus (PPV) Acta Biochim. Pol. 41:87-95. 